\title{
THE OVEREDUCATION PHENOMENON IN EUROPE
}

\section{EL FENÓMENO DE LA SOBRE-EDUCACIÓN EN EUROPA ${ }^{1}$}

\author{
SANTIAGO BUDRÍA \\ University of Madeira and CEEAplA. Portugal \\ sbudria@uma.pt \\ Ana I. Moro-Egido \\ University of Granada. España \\ aimoro@ugr.es
}

\begin{abstract}
The overeducation literature has typically assumed that the effect of overeducation on wages is constant across the conditional wage distribution. In this paper we use quantile regression and data from a group of European countries to show that differences across segments of the distribution are indeed large. We find significant differences between sexes, in the sense that it is not true that in countries where men are penalised more severely, women are also severely penalised. Moreover, different trends are observed depending on the country and sex. For example in Germany, the wage penalty for overeducation is higher among women than men. Furthermore, while the wage penalty for men increases from decile 10 to decile 90 , the wage penalty decreases for women. In Spain, women are more severely penalised for overeducation than men and the effect of overeducation is quite homogeneous across deciles for both men and women.
\end{abstract}

\section{AdDitional KeYWORDS}

Conditional Distribution of Wages, European Community Household Panel, Pay-penalty, Quantile Regression, Unobservable Variables.

\section{RESUMEN}

En la literatura relacionada con la sobre-educación, es tradicional asumir que el impacto de dicha sobreeducación en los salarios es común a toda la distribución de salarios. En este artículo, con datos de un grupo de países europeos y utilizando la regresión cuantílica se demuestra que, de hecho, el impacto de la sobreeducación es diferente en los distintos segmentos de la distribución de salarios. Las diferencias de género y por país son también significativas. Así por ejemplo en Alemania, la penalización salarial de los sobreeducados es mayor entre las mujeres que entre los hombres, pero mientras para los hombres la penalización es mayor en los deciles superiores, para las mujeres la penalización es mayor en los deciles inferiores. En España, las mujeres son más severamente penalizadas por estar sobre-educadas que los hombres, siendo constante dicha penalización salarial a lo largo de la distribución de salarios.

${ }^{1}$ We would like to thank the participants in the seminar at the University of Granada and EALE 2006 in Prague for their comments and suggestions. Santiago Budria is grateful for the funding provided under the EDWIN project HPSE-CT-2002-00108 of the European Commission and the FCT of the Ministry of Science and Education of Portugal. Ana I. Moro-Egido thanks the Centre for Andalusian Studies and Project SEJ2006-11067/ECON of the Spanish Ministry of Education and Science for their funding. 
Palabras clave Adicionales

Distribución condicional de salarios, Encuesta Panel de Hogares Europeo, Penalización salarial, Regresión cuantílica, Variables inobservables.

\section{INTRODUCTION}

Investment in human capital is a key element of economic progress. Nonetheless, recent research has shown that a great many countries have a significant number of workers with surplus schooling, that is, workers whose education exceeds their particular job requirements. This phenomenon, known as "overeducation", raises important questions on the efficiency of the educational system. Presumably, overeducated workers do not put all of their skills to full use; skills which have been attained following costly investments in education and at a great expense to the economy, firms and individuals. On the other hand, and from the standpoint of time, the existence of overeducated workers seems to suggest that the true economic benefits to be gained from the expansion of education in recently developed economies could actually be lower than expected.

Until now, the literature has focused primarily on determining the wage effects associated to overeducation and, secondarily, on verifying if these effects are due to the lack of adequate jobs or if instead they are a result of the lack of basic skills in workers classified as overeducated. In this paper we will deal with both of these issues. First, we will discuss the different theories that explain the existence of overeducated workers. Secondly, we will analyse the impacts of overeducation on wages for a group of European countries. To take the analysis one step further, we will explore the case of men and women separately.

Finally, two novel methodological approaches are introduced in this chapter. Firstly, an international database is used that allows cross-country comparisons to be made. This is a valuable tool for identifying common patterns that are key features of the economic phenomenon under study. The second contribution is the use of quantile regression, an econometric procedure that has certain advantages over the conventional approaches used in the literature.

\section{Theoretical Framework}

The term overeducation refers to a situation in which an individual possesses a higher level of education than that which is required for a given job. Although the scope of this phenomenon varies across countries and depending on the databases and measurement approaches used, it has been clearly shown that a significant proportion of workers is overeducated.

The available evidence indicates that, within the same educational level, overeducated workers earn less than their counterparts. According to Dolton and Vignoles (2000), the 
estimated differential is $12 \%$, while it is $18 \%$ in Dolton and Silles (2001), $27 \%$ in Chevalier (2003) for the UK, 11\% in Cohn and Kahn (1995), 13\% in Verdugo and Verdugo (1989) for the US; 26\% in Groot (1993) for Holland and 8\% in Kiker et al. (1997) for Portugal. Other studies make a distinction between the years of schooling required for a particular job position and the number of years the worker exceeds the required educational level. The general conclusion is that the return to surplus education is $50 \%$ less than the return to required education (Duncan and Hoffman, 1981, Hartog and Oosterbeek, 1988, Sicherman, 1991, Alba-Ramírez, 1993).

These results pose a challenge to Becker's Human Capital Theory (1964). The central assumption of this theory is that individuals are paid according to their marginal product, which is determined according to their human capital. Yet data show that workers who apparently have the same level of human capital earn different wages depending on if they are overeducated or not. This evidence could be rationalised by the HCT framework if wage inequalities were a short-term phenomenon, that is, if they were the result of transitory disequilibria that occur while companies adjust their production processes to fully utilise their workers' human capital, or, alternatively, while the workers seek more adequate employment. Despite the fact that previous studies sustain this opinion (Sicherman, 1991, Alba-Ramirez, 1993), recent investigations have shown that a substantial proportion of workers remain for long periods of time at jobs for which they are overqualified (Robst, 1995, Rubb, 2003, Dolton and Vignoles, 2000, McGuinness, 2003a).

An alternative approach to this issue is to acknowledge that the wage equation commonly used to explain earnings fails to include a series of factors that may not only have an effect on the probability of being overeducated, but also on the probability of being underpaid. In this case, the wage effects of overeducation could be the result of omitted variables rather than a real economic problem. For example, less formal measures of human capital such as seniority or training can act as substitutes for more formal education (substitution hypothesis). Likewise, the overeducated may lack certain skills and abilities that are in fact necessary to obtain a job that matches their educational level (the skills-ability hypothesis). In this case, the wage penalty for overeducation would instead be a reflection of the lack of human capital due to these work-related shortcomings and therefore be a mere statistical artefact.

The results supporting these studies, however, are limited. In line with the substitution hypothesis, Duncan and Hoffman (1981), Sicherman (1991) and Sloane et al. (1999) show that overeducated workers generally have less experience and skills. In contrast, Groot (1996) argues that there is a cohort and not a substitution effect: younger workers, who are more educated, find it difficult to gain access to more qualified jobs since older workers already occupy these positions despite having lower qualifications. In the same line, Groot (1993) and Alba-Ramirez (1993) find no evidence to support the hypothesis that employers consider on-the-job training to be a substitute for formal education. On the other hand, Dolton and Vignoles (2000) show that the incidence of overeducation is similar among workers with different levels of experience. 
In support of the skills-ability hypothesis, Groot (1996) shows that the wage penalty due to overeducation increases with experience. Sloane et al. (1999) conclude that overeducated workers are likely to have less chance of promotion due to their lower skills. This evidence, however, is less convincing when contrasted with studies that explicitly control for skill and ability heterogeneity. McGuiness (2003b) and Chevalier (2003) extend the wage equation framework to account for differences in skills and show that the wage penalty of overeducation continues to be significant in the resulting model. Using panel data to control for unobservable heterogeneity, Bauer (2002) found that around $30 \%$ of the estimated penalty can be explained by individual effects. McGuiness (2003a) and Green et al. (1999) stress the need to differentiate between education-based disequilibria and skill-based disequilibria. McGuiness (2003a) demonstrates that a large proportion of the overeducation wage penalty is independent of the extent to which productive skills are put to use in the workplace. Likewise, Green et al. (1999) show that even in the case of workers who are not overeducated, the correlation between real and required knowledge is far from perfect. Furthermore, the effects of being overeducated prove to be almost as important as the effects of being overqualified. Finally, McGuiness and Bennet (2006) use quantile regression to analyse possible differences between highly-qualified workers and under-skilled workers. They observe that the wage penalty associated to overeducation is particularly high among the most highly-qualified women.

To sum up, we conclude that the central assumptions of the Human Capital Theory cannot be fully explained by differences in the wage equation, although the inclusion of certain job characteristics and some type of control for heterogeneity can significantly affect the estimated relationship between overeducation and earnings.

This scenario has led many researchers to attempt to interpret the phenomenon of overeducation within the context of alternative labour market theories. Generally speaking, the theories that explain overeducation can be classified into three groups: (i) those based on labour market supply; ii) those based on labour market demand and (iii) those based on the balanced forces of labour market supply and demand. The Theory of Human Capital (THC) belongs to the first group of theories. A variant of the $\mathrm{TCH}$, known as the Theory of Career Mobility (TCM, Galor and Sicherman, 1990), suggests that workers with high levels of formal education accept positions for which they are apparently overeducated while they gain experience and specific human capital through on-the-job training. This permits them to subsequently move into positions where they can utilise their qualifications, either within the same firm or at a different one. The available evidence, however, is not conclusive with regard to this issue. Sicherman (1991) and Sloane et al. (1999) show that overeducated workers have less experience in the labour market and a lower level of training. In contrast, Alba-Ramirez (1993) finds that employers do not regard job experience or on-the-job training to be a substitute for formal qualifications.

The second group of theories related to the demand for labour focuses on the idea that education is a signal for companies. According to Thurow's Job Competition Model (JCM, 1975), workers are ranked according to their educational level as a signal of their 
capacity to learn and to hold the highest paying jobs. The JCM underlines the importance of a person's relative position on the list of job candidates. Overeducation could therefore be explained as an individual response by workers to defend their position on the list. This strategy, however, leads to the displacement of workers in the distribution of jobs, that is, overeducated workers will be forced to accept lower-paying jobs, while individuals at the lower end of the educational scale will be obligated to accept underpaid jobs or may even be crowded out of the labour market altogether.

The Educational Credential Hypothesis (ECH, van der Meer and Wielers (1996)) is based on the idea that large organisations and/or firms in the financial and professional services sector find it more difficult to devise mechanisms to measure workers' productivity and therefore place their trust in educational credentials. In the same line, the Signalling Theory (Spence, 1973) emphasises the role of education (or surplus schooling) as a filter that is used by employers to distinguish between highly productive and underproductive workers.

Finally, there is another subset of theories that focuses on the inefficiency of the process of assignment resulting from the forces of supply and demand. The Assignment Theory (AT, Sattinger 1993) holds that the marginal product, and therefore earnings, are determined by a worker's human capital and, at the same time, by the productivity ceiling of a particular job. As a result of this process of assignment, some workers hold job positions for which they do not possess comparative advantages and consequently end up earning lower wages. Within this context, overeducation is simply another form of inefficient assignment. While the Theory of Job Matching (Jovanovic, 1979) supports this view, it also attempts to determine if the costs of job search and imperfect information are reason enough to explain the existence of inefficient assignment.

\section{Methodology}

The results of this article are based on estimating a wage equation that includes conventional controls in addition to a variable for overeducation. Specifically, the estimated model is:

$$
\ln w_{i}=\alpha+\delta \cdot X_{i}+\beta \cdot \text { over }_{i}+e_{\theta i}
$$

where $I n$ wis the logarithm of monthly earnings, $X$ is a matrix that contains the conventional explanatory variables (education, seniority, experience, sector, firm size and type of contract, among others) and over is a dichotomous variable that takes a value of one when the worker is overeducated and a value of zero in the opposite case. The coefficient of this variable, $\beta$, captures the percentage effect of overeducation on earnings.

To estimate the model, we use Ordinary Least Squares (OLS) and Quantile Regression 
(QR). The model specification for the Quantile Regression case is

$$
\text { In } w_{i}=X_{i} \beta_{\theta}+e_{\theta i} \quad \text { with Quant }{ }_{\theta}\left(\ln w_{i} \mid X_{i}\right)=X_{i} \beta_{\theta}
$$

where $X$ is the vector of the explanatory variables indicated for the OLS specification and and $\beta_{\theta}$ is the vector of the parameters. Quant $\theta(I n$ wi $X i)$ denotes the $\theta$ th decile of the variable In $w$ given vector $X$. By using some simplifications, the vector of the parameters solves the following problem:

$$
\operatorname{Min}_{\beta \varepsilon R^{k}}\left\{\sum_{i} p_{\theta}\left(\ln w_{i}-X_{i} \beta_{\theta}\right)\right\}
$$

This problem is solved using linear programming methods in which the standard errors for the vector of the coefficient are obtained using the bootstrap method proposed by Buchinsky (1994).

The application of the QR regression to the study of overeducation is a novel approach with two important advantages ${ }^{2}$. First, the literature to date has assumed that wage effects on overeducation are uniform along the conditional distribution of wages. However, there is nothing to guarantee that the differential between the wages of an overeducated worker and a worker who is not overeducated will be the same when analysing well-paid jobs and underpaid jobs. The QR estimate permits this differential to be measured at different points of the distribution, thus providing a more differentiated view.

Secondly, in the quantile regression framework, the estimates at different quantiles represent the effects of a given covariate for individuals that have the same observable characteristics but, due to unobservable earnings capacity, are located at different quantiles of the conditional distribution. Assuming that unexplained earnings capacity is given by the individuals' unobserved ability (where by ability we refer to those marketable skills, academic credentials and motivations that allow a worker to earn a higher wage given a vector of observable characteristics), with $Q R$ we can therefore document how workers who are mismatched within the various ability segments of the earnings distribution are impacted relative to their well-matched counterparts. Having the labour market segmented by ability deciles, with individual ability indexed by the individual's position in the conditional wage distribution, the estimates at different quantiles provide snap-shots of how overeducated individuals within the different ability groups are impacted. While in the majority of jobs the effect of overeducation on earnings is estimated for a representative individual with an average ability level, in this study we explore the different effects of overeducation on individuals with different and non-observable abilities. As we will see below, the results provide important insight into the phenomenon of overeducation

\footnotetext{
${ }^{2}$ See Koenker and Hallock (2001) for an introduction to the QR estimate and its applications.
} 


\section{DATABASES AND DEFINITION OF OVEREDUCATION}

As we stated above, an overeducated individual is one who has a higher level of education than that required to perform a particular job. In spite of this being a widely-accepted definition, different approaches have been used to measure overeducation, albeit each has its own particular limitations ${ }^{3}$. Following other authors, in our study we use workers' assessments regarding the "match" between their education and knowledge and the requirements of their job. We use data from the most recent wave of the European Community Household Panel (hereafter ECHP) dating from 20014. This database includes two questions that were previously used by Alba-Ramírez and Blázquez (2002) and Budría and Moro-Egido (2007a). The first question captures the "quantitative" aspect of this mismatch:

Do you feel that you have skills or qualifications to do a more demanding job than the one you now have?

This question aims to identify the group of overqualified workers (those who answer 'yes'). This measurement, however, constitutes a "weak" definition of overeducation as its does not reflect the educational mismatch that occurs when the type (not the level) of education is inadequate. Thus, a language specialist who works as a financial consultant would not define herself as being overqualified, but would acknowledge that her formal training was not adequate for her present type of work. To capture the "qualitative" aspect of this mismatch, we explore the following question:

Have you had formal training or education that has given you the skills needed for your present type of work?

This information allows us to identify "incorrectly qualified" individuals. In this article we consider overeducated workers solely to be those who answer 'yes' to the first question and 'no' to the second, that is, individuals who are overqualified and also lack adequate training. We therefore use the robust definition proposed by Budría and Moro-Egido (2007a).

\footnotetext{
${ }^{3}$ There are basically three approaches to measuring overeducation: job analysis, a statistical approach and workers' own assessments. For a description of these methods see Hartog (2000) and Sloane (2002).

${ }^{4}$ The ECHP is a representative survey conducted for 15 European countries. The principal advantage to the ECHP is that due to its standardized design, direct comparisons may be made across countries. The survey covers a wide range of topics related to the personal and job characteristics of the individuals concerned including monthly income, educational level, hours worked per week, occupation, experience, sector, size of firm or organization, civil status and immigrant status.
} 


\section{EMPIRICAL EVIDENCE FOR EUROPE}

Although the topic that interests us here has already been explored by a variety of countries for a number of years, the existing results do not permit direct comparisons to be made across countries due to the large discrepancies encountered in the earnings, databases and definitions of overeducation in the different studies.

Budría and Moro-Egido (2007b) propose a common framework that permits international comparisons to be made. To this end, they use the same wage equation, comparable databases and an identical definition of overeducation for each country. Therefore, unlike previous research, the major advantage to this study is its comparability, a key element in establishing robust and consistent evidence for the phenomenon under study. The second contribution of this study is that the results are based on quantile regression. In what follows we will discuss the principle results of the study, extend them to include the case of women and provide a more in-depth examination of the case of Spain in particular.

Table 1 shows the percentages of "overqualified", "incorrectly qualified" and "overeducated" workers in Europe. The incidence of overqualified workers in Europe is $59.5 \%$, ranging from $41.6 \%$ in Portugal to $68.25 \%$ in the United Kingdom. On the other hand, the percentage of workers with an "incorrect" education is lower and ranges from $20.5 \%$ in Germany to $68.1 \%$ in Portugal, with an average of $42.5 \%$. Finally, the proportion of overeducated workers is $21.9 \%$ on average and ranges from $14.3 \%$ in Germany to $30.4 \%$ in Italy.

In Spain, the proportion of overqualified, incorrectly qualified and overeducated workers is $59.4 \%, 47.5 \%$ and $25.0 \%$, respectively. These data place Spain slightly above the European average in terms of the current educational mismatch in the labour market.

Table 1.

Descriptive statistics on overeducation

\begin{tabular}{lcccccccc}
\hline & Europe & France & Germany & Greece & Italy & Portugal & Spain & UK \\
\hline Overqualified & 59.46 & 55.25 & 67.82 & 49.11 & 48.46 & 41.63 & 59.44 & 68.26 \\
Incorrect qualification & 42.49 & 48.23 & 20.46 & 64.94 & 67.91 & 68.07 & 47.45 & 31.74 \\
Overeducation & 21.92 & 23.68 & 14.29 & 29.81 & 30.35 & 25.47 & 25.01 & 19.42 \\
\hline
\end{tabular}

An overall estimate for the different countries shows that overeducated workers in Europe earn on average $7.7 \%$ less, ceteris paribus, than workers with the same educational level who are not overeducated. This data is broken down by country and sex in Figure 1. The criterion for ranking is male wage penalty, which iowest in France $(5 \%)$ and highest in Greece (over 20\%). The cross-country comparability of the ECHP permits us to conclude 
that: i) the wage penalty due to overeducation is generally quite marked and ii) the estimates obtained are more homogeneous than those found in the literature (Hartog, 2000, McGuinness, 2006).

Figure 1.

Wage effect of overeducation

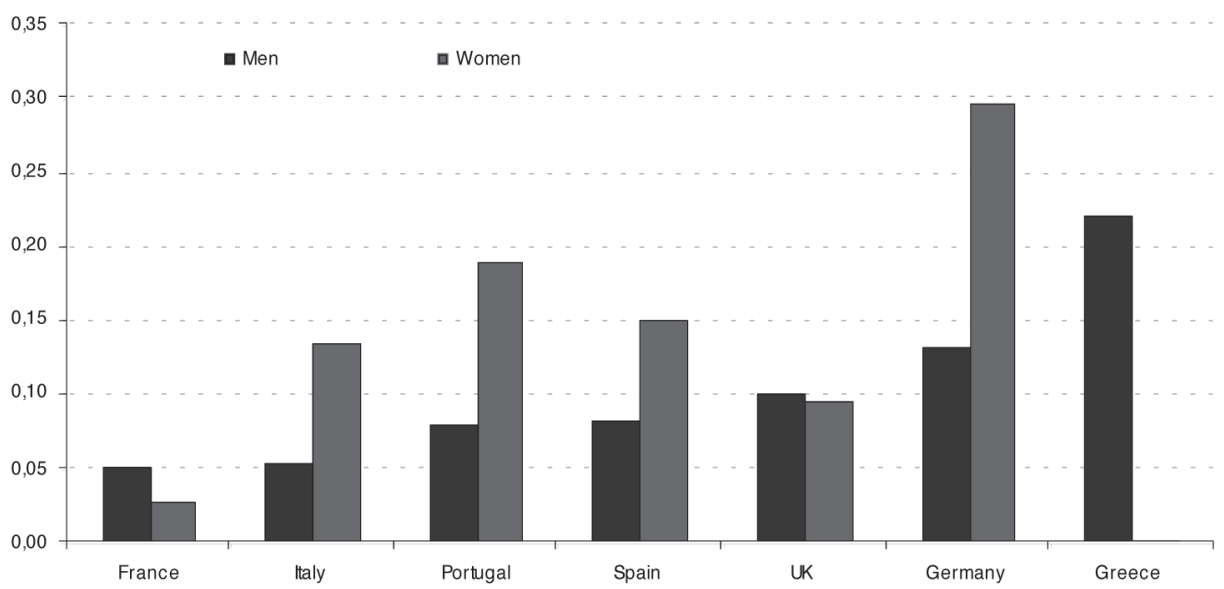

Significant differences are found between sexes. In general, it is not true that in countries where men are penalised more severely, women are also severely penalised. Thus, we see that women in Germany are paid almost 30\% less if they are overeducated, while the same effect does not reach $15 \%$ in men. In Greece, however, the estimated $22 \%$ among males contrasts with the almost null affect among females. In the case of women, differences across countries may be due to the different rates of female participation in the labour market. In Greece, the percentage of women who participate in the labour market is relatively low and may therefore be comprised of women who have high earnings regardless of whether they are overeducated or not. The opposite argument may hold for Germany; a country in which the majority of women work. In this case, women are affected by the same phenomena as men.

As we pointed out above, the mean effect of overeducation could be masking different effects in the wage distribution. The estimated parameters and the standard errors are shown in the Table 2. Figure 2 shows the results of the quantile regression. Estimates are shown for each decile and country, including the lowest 10\% (Q10) to the highest $90 \%(Q 90)$ and the mean estimate (OLS). The main conclusion is that the estimated coefficient is not generally constant along the distribution. Moreover, different trends are observed depending on the country. 
In Germany, the wage penalty for overeducation is higher among women than men. Furthermore, men and women show opposing trends. While the wage penalty for men increases from decile 10 to decile 90 , the wage penalty decreases in women, although both effects equal out at decile 90 .

In Spain, women are more severely penalised for overeducation than men. On the other hand, the effect of overeducation is quite homogeneous across deciles for both men and women. This pattern, which is also observed in Italy, suggests that the estimated mean effect describes in a reasonably good manner what occurs along the entire wage distribution.

France and Portugal share similar characteristics. Both sexes show similar and increasing effects along the wage distribution.

In Greece, the effects of overeducation are inexistent for women, perhaps due to their lower rate of employment. In the case of men, the estimated effect decreases when approaching the highest deciles.

The United Kingdom merits special attention as it is a good example of how the mean effect can mask other types of effects. In the UK, the mean effect of overeducation is identical for men and women. However, marked differences are found by sex across the different deciles. While the wage penalty for men increases along the distribution, the estimated effect for women clearly decreases in the upper half of the wage distribution.

On the whole, these results provide new clues to the causes and effects of overeducation. The differences observed across deciles suggest the existence of a subtle interrelation between non-observable individual characteristics and the impact of overeducation on wages. Among researchers the debate has revolved around a single issue: whether or not the incidence of overeducation leads to a loss of productivity. This could be the case of potentially productive workers who are forced to accept jobs for which they are overeducated and which impose restrictions on their productivity. If, in contrast, overeducation is a phenomenon that, in reality, is a consequence of the lack of individual abilities and skills, then its effects are a mere statistical artefact. It is precisely here where the $\mathrm{QR}$ analysis becomes important.

The $Q R$ regression discriminates between workers whose non-observable skills make them highly productive (those who are situated in the highest deciles of the conditional wage distribution) and workers who are under-skilled (those located at the tail end of the distribution). If overeducation were the consequence of a lack of job-related skills, as some authors argue, then the effects of overeducation would be concentrated in the lowest segments of the conditional wage distribution, that is, among the least-qualified workers. However, estimates show that the effects of overeducation are also significant in the highest deciles. Thus, we observe that in Germany, Italy, Portugal and the United Kingdom the estimated effects for men are in fact higher in the highest deciles. In these cases, the workers who are most affected by overeducation are precisely those with the highest productive capacity.

In light of these results, we conclude that the consequences of overeducation are not a mere statistical outcome produced by a lack of unobservable skills. Instead, they seem 
Table 2.

Estimation Results

\begin{tabular}{|c|c|c|c|c|c|c|c|}
\hline MEN & Germany & Spain & France & Greece & Italy & Portugal & UK \\
\hline OLS & $\begin{array}{c}-0.132^{* * *} \\
{[0.047]}\end{array}$ & $\begin{array}{l}-0.082 \\
{[0.087]}\end{array}$ & $\begin{array}{l}-0.053 \\
{[0.051]}\end{array}$ & $\begin{array}{c}-0.222^{\star *} \\
{[0.111]}\end{array}$ & $\begin{array}{l}-0.055 \\
{[0.043]}\end{array}$ & $\begin{array}{l}-0.079 \\
{[0.079]}\end{array}$ & $\begin{array}{l}-0.100^{*} \\
{[0.057]}\end{array}$ \\
\hline Q10 & $\begin{array}{l}-0.002 \\
{[0.055]}\end{array}$ & $\begin{array}{c}-0.094^{* * *} \\
{[0.035]}\end{array}$ & $\begin{array}{l}-0.067^{* *} \\
{[0.040]}\end{array}$ & $\begin{array}{l}-0.059 \\
{[0.048]}\end{array}$ & $\begin{array}{c}-0.081^{* * *} \\
{[0.016]}\end{array}$ & $\begin{array}{l}-0.040^{*} \\
{[0.032]}\end{array}$ & $\begin{array}{c}-0.106^{* * *} \\
{[0.031]}\end{array}$ \\
\hline Q25 & $\begin{array}{l}-0.071^{*} \\
{[0.040]}\end{array}$ & $\begin{array}{c}-0.091^{* * *} \\
{[0.033]}\end{array}$ & $\begin{array}{l}-0.088 \\
{[0.032]}\end{array}$ & $\begin{array}{c}-0.102^{* * *} \\
{[0.030]}\end{array}$ & $\begin{array}{l}-0.044^{* *} \\
{[0.026]}\end{array}$ & $\begin{array}{l}-0.000 \\
{[0.023]}\end{array}$ & $\begin{array}{l}0.029 \\
{[0.027]}\end{array}$ \\
\hline Q50 & $\begin{array}{c}-0.099^{* * *} \\
{[0.024]}\end{array}$ & $\begin{array}{l}-0.090 \\
{[0.024]}\end{array}$ & $\begin{array}{l}-0.084^{* *} \\
{[0.021]}\end{array}$ & $\begin{array}{c}-0.155^{\star \star *} \\
{[0.029]}\end{array}$ & $\begin{array}{c}-0.061^{* * *} \\
{[0.014]}\end{array}$ & $\begin{array}{l}-0.014 \\
{[0.038]}\end{array}$ & $\begin{array}{c}-0.102^{* * *} \\
{[0.043]}\end{array}$ \\
\hline Q75 & $\begin{array}{c}-0.112^{* * *} \\
{[0.029]}\end{array}$ & $\begin{array}{c}-0.071^{* *} \\
{[0.031]}\end{array}$ & $\begin{array}{c}-0.044^{* *} \\
{[0.031]}\end{array}$ & $\begin{array}{c}-0.104^{* * *} \\
{[0.121]}\end{array}$ & $\begin{array}{l}-0.055 \\
{[0.020]}\end{array}$ & $\begin{array}{l}-0.048^{*} \\
{[0.025]}\end{array}$ & $\begin{array}{l}-0.080^{*} \\
{[0.082]}\end{array}$ \\
\hline Q90 & $\begin{array}{c}-0.150^{* * *} \\
{[0.037]}\end{array}$ & $\begin{array}{c}-0.107^{* * *} \\
{[0.070]}\end{array}$ & $\begin{array}{c}-0.089^{* * *} \\
{[0.054]}\end{array}$ & $\begin{array}{c}-0.251^{* *} \\
{[0.041]}\end{array}$ & $\begin{array}{c}-0.052^{* * *} \\
{[0.046]}\end{array}$ & $\begin{array}{c}-0.091^{* * *} \\
{[0.023]}\end{array}$ & $\begin{array}{c}-0.129^{* * *} \\
{[0.039]}\end{array}$ \\
\hline N. Obs. & 2333 & 2540 & 1770 & 1379 & 2357 & 2391 & 1570 \\
\hline \multicolumn{8}{|c|}{$\begin{array}{l}\text { Standard errors shown in brackets. } \\
{ }^{*} \text { Significant at } 10 \% \text {; }{ }^{*} \text { significant at } 5 \% \text {; }{ }^{* *} \text { significant at } 1 \%\end{array}$} \\
\hline WOMEN & Germany & Spain & France & Greece & Italy & Portugal & UK \\
\hline OLS & $\begin{array}{l}-0.296^{* * *} \\
{[0.087]}\end{array}$ & $\begin{array}{l}-0.251^{*} \\
{[0.150]}\end{array}$ & $\begin{array}{l}-0.027 \\
{[0.074]}\end{array}$ & $\begin{array}{c}0.003 \\
{[0.144]}\end{array}$ & $\begin{array}{l}-0.136^{* *} \\
{[0.058]}\end{array}$ & $\begin{array}{l}-0.189^{*} \\
{[0.104]}\end{array}$ & $\begin{array}{l}-0.095 \\
{[0.062]}\end{array}$ \\
\hline Q10 & $\begin{array}{c}-0.404 \\
{[0.443]}\end{array}$ & $\begin{array}{l}-0.187^{* *} \\
{[0.137]}\end{array}$ & $\begin{array}{c}-0.130^{* * *} \\
{[0.032]}\end{array}$ & $\begin{array}{l}-0.041 \\
{[0.030]}\end{array}$ & $\begin{array}{l}-0.113^{\star * *} \\
{[0.036]}\end{array}$ & $\begin{array}{l}-0.066 \\
{[0.045]}\end{array}$ & $\begin{array}{l}-0.038 \\
{[0.038]}\end{array}$ \\
\hline Q25 & $\begin{array}{c}-0.221^{* * *} \\
{[0.070]}\end{array}$ & $\begin{array}{l}-0.125^{* *} \\
{[0.035]}\end{array}$ & $\begin{array}{c}0.087 \\
{[0.024]}\end{array}$ & $\begin{array}{l}-0.056 \\
{[0.114]}\end{array}$ & $\begin{array}{c}-0.085^{\star * *} \\
{[0.027]}\end{array}$ & $\begin{array}{c}-0.048^{* *} \\
{[0.026]}\end{array}$ & $\begin{array}{l}-0.051 \\
{[0.257]}\end{array}$ \\
\hline Q50 & $\begin{array}{c}-0.154^{* * *} \\
{[0.039]}\end{array}$ & $\begin{array}{c}-0.157^{\star * *} \\
{[0.053]}\end{array}$ & $\begin{array}{l}-0.019 \\
{[0.033]}\end{array}$ & $\begin{array}{l}-0.066 \\
{[0.045]}\end{array}$ & $\begin{array}{l}-0.058^{*} \\
{[0.033]}\end{array}$ & $\begin{array}{l}-0.041 \\
{[0.082]}\end{array}$ & $\begin{array}{l}-0.098 \\
{[0.074]}\end{array}$ \\
\hline Q75 & $\begin{array}{c}-0.123^{* * *} \\
{[0.030]}\end{array}$ & $\begin{array}{c}-0.132^{* * *} \\
{[0.039]}\end{array}$ & $\begin{array}{c}-0.092^{* * *} \\
{[0.075]}\end{array}$ & $\begin{array}{c}-0.082^{* * *} \\
{[0.026]}\end{array}$ & $\begin{array}{c}-0.113^{\star * *} \\
{[0.048]}\end{array}$ & $\begin{array}{c}-0.146^{\star * *} \\
{[0.044]}\end{array}$ & $\begin{array}{l}-0.221 \\
{[0.046]}\end{array}$ \\
\hline Q90 & $\begin{array}{c}-0.133^{\star * *} \\
{[0.036]}\end{array}$ & $\begin{array}{l}-0.113 \\
{[0.077]}\end{array}$ & $\begin{array}{c}-0.082^{* * *} \\
{[0.029]}\end{array}$ & $\begin{array}{l}-0.062 \\
{[0.045]}\end{array}$ & $\begin{array}{l}-0.098^{* *} \\
{[0.017]}\end{array}$ & $\begin{array}{l}-0.030 \\
{[0.022]}\end{array}$ & $\begin{array}{c}0.022 \\
{[0.046]}\end{array}$ \\
\hline N. Obs. & 1645 & 1599 & 1512 & 921 & 1609 & 1932 & 1382 \\
\hline
\end{tabular}

Standard errors shown in brackets.

${ }^{*}$ significant at $10 \%$; ** significant at $5 \%$; ${ }^{* * *}$ significant at $1 \%$

to be the result of an imperfect relationship between workers' potential productivity and the maximum possible productivity of the job. Furthermore, this mismatch can affect all types of workers, regardless of their unobservable characteristics. 
Figure 2.

The effect of overeducation on wages - Analysis by quantiles.
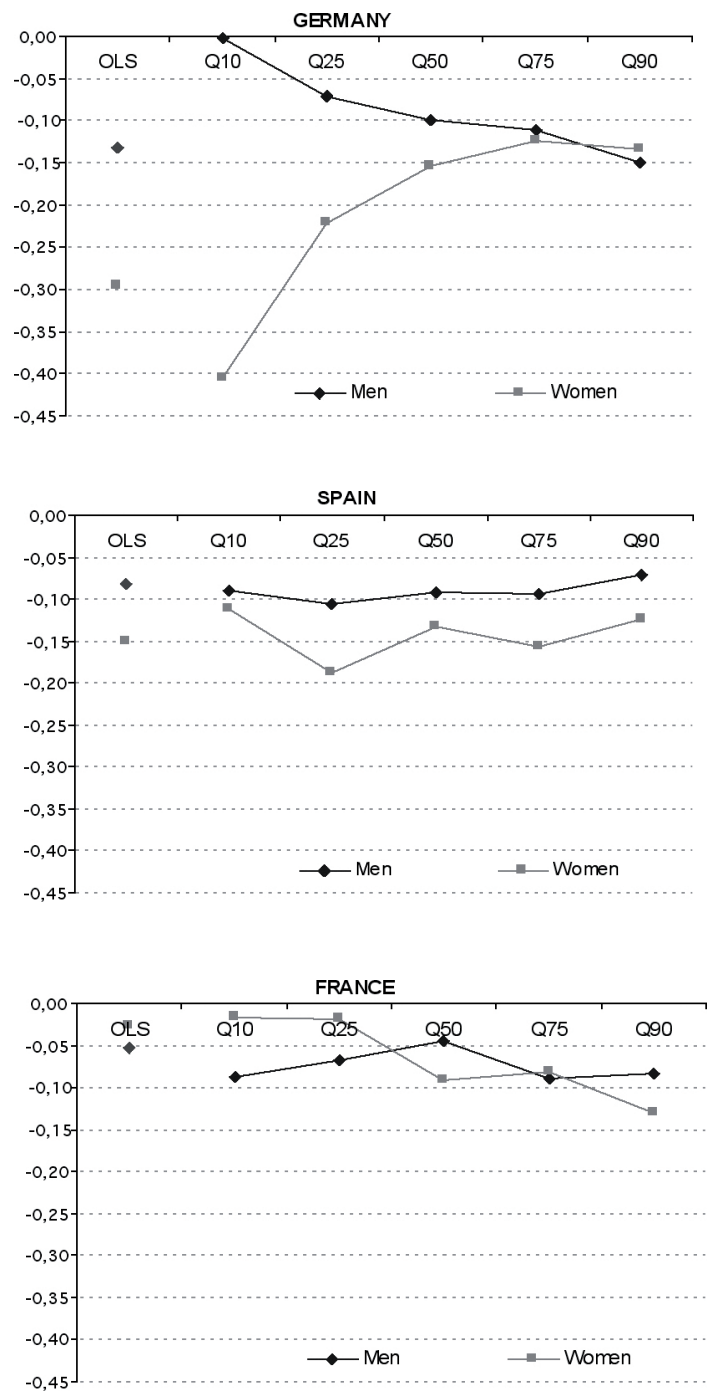

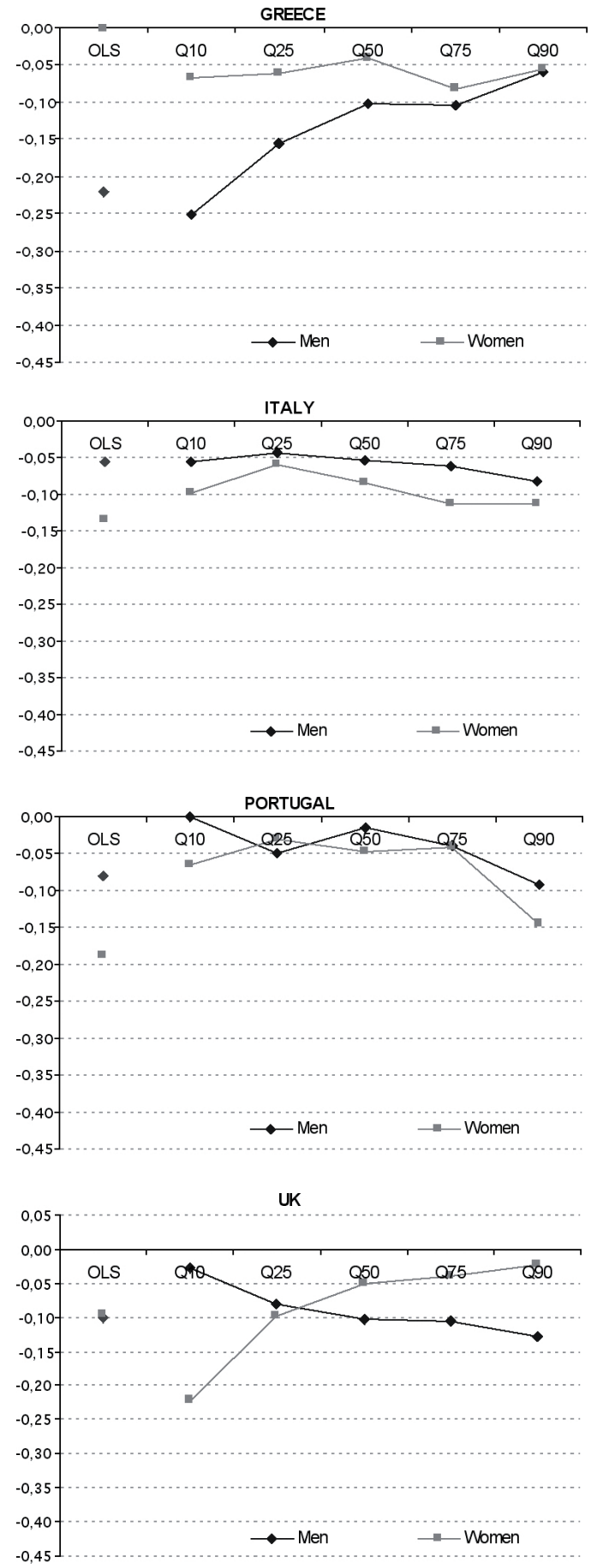

RIS, VOL. 67, NN 2, MAYO-AGOSTO , 329-345, 2009. ISSN: 0034-9712 
Finally, our results suggest the need to undertake two practices with regard to the research into this phenomenon. First, the observed differences between quantiles point to the importance of not restricting estimates to mean effects; a procedure that, to date, has been commonplace in the literature. Secondly, the differences that exist between men and women, which are applicable to both the mean effects and the quantile profiles of overeducation, underline the need to specifically examining this phenomenon by sex. It is here where comparative studies can aid us in gaining a better understanding of the particular characteristics of overeducation.

\section{Conclusions}

A significant proportion of the labour force in developed countries is overeducated, that is, workers have surplus schooling. This phenomenon has attracted growing attention in the literature due to the possible impact it may have on the efficiency of the educational system and the functioning of the labour market.

In this chapter we have analysed the wage effects of overeducation. To do so we have used comparable data from a set of European countries and two complementary econometric approaches: the OLS estimate and the QR estimate.

In Europe, the mean wage penalty for overeducated workers is around $7.7 \%$. In spite of the fact that this figure fluctuates slightly across countries and sexes, it is evident and statistically significant. We show that the estimated effect fluctuates along the conditional wage distribution. Specifically, we observe that in Germany, France, Greece, Portugal and the United Kingdom, the QR analysis provides more information than the OLS analysis. This fact underlines the importance of not restricting the analysis of the wage effect of overeducation solely to its mean effects, a practice that has been commonplace in the literature until now.

In light of the results of our study, there exist sound reasons for economic and educational policymakers to seriously take into account the phenomenon of overeducation. Like unemployment, overeducation is an indicator of the extent to which labour markets do not fully utilise the available human capital. Dolado et al. (2000) show that in recent years less-educated workers have been displaced from traditional occupations to jobs requiring no qualifications, while a large proportion of university graduates have taken up positions that require a low educational level. Bearing in mind that education is an individual investment, this has led to enormous costs in terms of resources. On the other hand, our results show that if the proportion of overeducated workers continues to rise, wage inequalities will also increase within each educational group. This trend could have important implications for wage distribution in Spain and the type and level of education that will be in demand in generations to come, two issues which will form part of our future research agenda. 


\section{REFERENCES}

Alba, A. and M. Blázquez (2002), Types of Job Match, Overeducation, and Labour Mobility in Spain, in Büchel, F., A. de Grip and A. Meitens (eds), Overeducation in Europe: Current Issues in Theory and Policy. Edward Elgar Publishing: Cheltenham, UK.

Alba-Ramírez, A. (1993), "Mismatch in the Spanish Labour Market. Overeducation?", Journal of Human Resources 28: 259-278.

Bauer, T. (2002), "Educational mismatch and wages: a panel analysis", Economics of Education Review 21: 221-229.

Becker, G. (1964), Human Capital: A Theoretical and Empirical Analysis with Special Reference to Education. New York: Columbia University Press.

Buchinsky, M. (1994), "Changes in the US Wage Structure 1963-1987: Application of Quantile Regression", Econometrica 62, 405-458.

Budría, S. and A.I. Moro-Egido (2007a), "Education, Educational Mismatch, and Wage Inequality: Evidence for Spain", Economics of Education Review 27: 332-341.

(2007b) "Overeducation and Wages in Europe: Evidence from Quantile Regression", WP EEE(ETS) Fedea n. 221.

Chevalier, A. (2003), "Measuring over-education", Economica 70: 509-531.

Cohn, E. and P. Khan, (1995), "The wage effects of overschooling revisited", Labour Economics 2: 67-76.

Dolado, J.J., F. Felgueroso and J.F. Jimeno (2000), "Explaining Youth Labor Market Problems in Spain: Crowding-out, Institutions, or Technology Shifts?", IZA Discussion Paper 142.

Dolton, P. and A. Vignoles (2000), "The incidence and effects of over-education in the UK graduate labour market", Economics of Education Review 19: 179-98

Dolton, P. and M. SilLes (2001), "Over-education in the Graduate Labour Market: Some Evidence from Alumni Data", Centre for the Economics of Education, Discussion Paper Series 9.

Duncan, J. and S. Hoffman (1981), "The incidence and wage effects of overeducation", Economics of Education Review 1: 75-86.

Galor O. and N. Sicherman.(1990), "A theory of Career Mobility", Journal of Political Economy 98: 169-192.

Green, F., Mclntosh, S. and A Vignoles (1999), Overeducation and Skills: Clarifying the Concepts, London: Centre for Economic Performance

Groot, W. (1993), "Overeducation and the returns to enterprise related schooling", Economics of Education Review 17: 299-309.

(1996), "The incidence of, and returns to overeducation in the UK", Applied Economics 28: 1345-1350. 
Hartog, J. (2000), "Over-education and earnings: where are we, where should we go?", Economics of Education Review 19: 131-147.

Hartog, J. and H. Oosterbeek (1988), "Education, allocation and earnings in the Netherlands: overschooling?", Economics of Education Review 7: 185-194

Jovanovic B. (1979), "Job Matching and the Theory of Turnover", Journal of Political Economy 87: 972-990.

Kiker, B., Santos, M. and M. Mendes de Oliveiria (1997), "Overeducation and undereducation: evidence for Portugal", Economics of Education Review 16: 111-125.

Koenker, R. and K. Hallock (2001), "Quantile Regression”, Journal of Economic Perspectives 15: 143-156.

McGuiness, S. (2003a), "Graduate overeducation as a sheepskin effect: evidence from Northern Ireland", Applied Economics 35: 597-608.

(2003b), "University quality and labour market outcomes", Applied Economics 35: 1943-1955.

(2006), "Overeducation in the Labour Market", Journal of Economic Surveys 20: 387-418.

McGuinness, S. and J. Bennett (2006), "Overeducation and the Graduate Labour Market: A Quantile Regression Approach", Economics of Education Review 26: 521-531

Robst, J. (1995), "College Quality and Overeducation", Economics of Education Review 14: 221-228.

Rubb, S. (2003), "Overeducation: A Short or Long Run Phenomenon for Individuals?", Economics of Education Review 22: 389-394.

Sattinger M. (1993), "Assignment Models of the Distribution of Earnings", Journal of Economic Literature XXXI: 831-880.

Sicherman, N. (1991), "Mismatch in the Labor Market", Journal of Labor Economics 9: 101-122.

Sloane, P. J. (2002), Much Ado About Nothing? What does the Over-education Literature really Tell Us? Keynote Address, International Conference on Over-education in Europe: What Do We Know? 22-23 November, Berlin.

Sloane, P.J., H. Battu and P.T Seaman (1999), "Over-education, Undereducation and the British Labour Force", Applied Economics 31: 1437-1453.

(1999), "Mismatch, Undereducation and the British Labour Force", Applied Economics 31, n. 11: 14371453.

Spence, M. (1973), "Job market signalling", Quarterly Journal of Economics 87: 355-374.

Thurow, L. (1975), Generating Inequality, New York: Basic Books.

Verdugo, R. and N.T. Verdugo (1989), "The impact of surplus schooling on earnings: Some additional findings", Journal of Human Resources 24: 629-695. 
Van der Meer P. and R. Wielers (1996), "Educational Credentials and Trust in the Labor Market", Kyklos, vol. 49, n. 1: 29-41.

RECIBIDO: $15 / 05 / 2007$

ACEPTADO: 26/11/2008 